Caries Res. 1983;17:I-VIII

\title{
Contents, Vol. 17, 1983
}

\section{Contents Vol. 17,1983}

\section{No. 1 Basic Sciences}

Scanning Electron Microscopy of the Human Enamel Surface Layer of Incipient Carious

Lesions

Haikel, Y.; Frank, R.M.; Voegel, J.C 1

Influence of HCIO4 Strength and Etching Time on Rate of Etching and Surface Roughness of Human Enamel

Dijkman, A.G.; Tak, J.; Jongebloed, W.L.; Arends, J

A Microanalytical Procedure for the Determination of Calcium, Phosphate and Fluoride in Enamel Biopsy Samples

Vogel, G.L.; Chow, L.C.; Brown, W.E

Fluoride-Exchanging Resins for Caries Protection

Rawls, H.R.; Zimmerman, B.F 32

Enamel Fluoride Uptake, Distribution and Retention from Topical Fluoride Agents

Retief, D.H.; Bradley, EX.; Holbrook, M.; Switzer, P 44

Effect of Packing Density and Polysaccharide to Protein Ratio of Plaque Samples Cultured in vitro upon Their Permeability

Dibdin, G.H.; Wilson, CM.; Shellis, R.P. 52

Isolation and Characterization of Intracellular Polysaccharide from Actinomyces viscosus

(Short Communication)

Komiyama, K.; Duncan, D.; Singer, D.L.; Khandelwal, R.L 59

Animal Studies

Initial Adherence and Minimum Infective Dose for Rats of Streptococcus mutans T2 Grown

Under Differing Conditions

Hoeven, J.S. van der; Rogers, A.H 62

Clinical Science

Effect of Dental Plaque on Fluoride Uptake by Enamel from a Sodium Fluoride Varnish in vivo

Seppä, L 71

Effect of 4 Days Consumption of Chewing Gum Containing Sorbitol or a Mixture of Sorbitol and Xylitol on Dental Plaque and Saliva

Birkhed, D.; Edwardsson, S.; Wikesjö, U.; Ahldén, M.-L.; Ainamo, J 76

IV Contents

Preeruptive Acquisition of Fluoride by Surface Enamel of Permanent Teeth after Daily Use of F Supplements (Short Communication)

Bruun, C; Poulsen, S.; Østergaard, V.; Højbjerg, R 89

Comparability of the Biochemical Composition of Dental Plaque Samples Collected from

14- to 15-Year-Old Males Using Plastic and Metal Instruments

(Short Communication) 
Ashley, F.P.; Wilson, R.F

92

Announcement 96

No. 2 Basic Sciences

Crystallite Diameters of Enamel near the Anatomical Surface. An Investigation of Mature, Deciduous and Non-Erupted Human Enamel

Arends, J.; Jongebloed, W.L.; Schuthof, J 97

Action of Urea Solutions on Human Enamel Surfaces

Goldberg, M.; Arends, J.; Jongebloed, W.L.; Schuthof, J.; Septier, D. . 106

Penetration of Fluoride and Chlorhexidine in Human Dental Plaque in vitro

Melsen, B.; Kaae, O.; Rölla, G 113

Distribution of Fluoride in Clinically Sound Enamel Surfaces of Permanent Upper Incisors

Weatherell, J.A.; Robinson, C; Schaper, R.; Künzel, W 118

Animal Studies

The Association between Dental Caries Incidence and Two Streptococcus mutans

Populations in Monkeys Macaca fascicularis

Beighton, D.; Cohen, B.; Hayday, H 125

Anticariogenicity of Dietary Glycerol Monolaurin in Rats

Lynch, P.; Schemmel, R.A.; Kabara, JJ 131

Clinical Science

Lithium Content, Buffering Capacity and Flow Rate of Saliva and Caries Experience of Australian Children

Agus, H.M.; Schamschula, R.G 139

The Effects of Changing Caries Prevalence and Diagnostic Criteria on Clinical Caries

Trials

Glass, R.L.; Peterson, J.K.; Bixler, D 145

Relative Contributions of the Dental Examiner and Local Dentists in Determining the

Caries Status of Subjects in Field Studies. Short Communication

Ripa, L.W.; Leske, G.S.; Sposato, A 152

Abstracts

Abstracts of Papers Presented at the 29th ORCA Congress. June 30-July 3, 1982, Annapolis, Md., USA 156

No. 3 Basic Sciences

Influence of Fluoride in Solution on Tooth Demineralization. I. Chemical Data

Cate, J.M. ten; Duijsters, P.P.E 193

Effect of Carbonate and Fluoride on the Dissolution Behaviour of Synthetic Apatites

Nelson, D.G.A.; Featherstone, J.D.B.; Duncan, J.F.; Cutress, T.W 200

Contents

$\mathrm{V}$

Calcium Release from Powdered Enamel and Synthetic Apatite after Pretreatment with

Various Low Molecular Weight Organic Acids

Voegel, J.C.; Gillmeth, S.; Frank, R.M 212

Effect of Surface-Active Agents on Fluoride-Enamel Interactions. I

Caslavska, V.; Gron, P 221

Binding of Polyphosphates and Phosphonates to Hydroxyapatite, Subsequent Hydrolysis, Phosphate Exchange and Effects on Demineralization, Mineralization and Microcrystal

Aggregation 
McGaughey, C

Abrasion of Enamel. I. An in vitro Investigation

Slop, D.; Rooij, J.F. de; Arends, J 242

Strontium Uptake and Enamel Dissolution in Bovine and Human Enamel

(Short Communication)

Curzon, M.E.J.; Spector, P.C 249

Inhibiting Effect of Aqueous Extracts of Eight Nigerian Chewing Sticks on Bacterial Properties

Favouring Plaque Formation (Short Communication)

Wolinsky, L.E.; Sote, E.0 253

Animal Studies

Fluoride Content and Calcium Release from Enamel, in Relation to Rat Caries following the Application of Fluoride Varnishes

Seppä, L.; Luoma, H 258

Effect of Systemic Titanium Tetrafluoride (TiF4) on Fluoride Uptake by Developing Rat

Enamel (Short Communication)

Shrestha, B.M 264

Clinical Science

A Four-Year Clinical Study to Determine the Caries-Inhibiting Effect of Calcium Glycerophosphate and Sodium Fluoride in Calcium Carbonate Base Dentifrices Containing

Sodium Monofluorophosphate

Mainwaring, P.J.; Naylor, M.N 267

Fluoride Ingestion with Fluoridated Domestic Salt under Swedish Dietary Conditions

Ericsson, Y.; Andersson, R 277

No. 4 Basic Sciences

Dissolution Rate Behavior of Hydroxyapatite-Fluorapatite Mixtures

Crommelin, D.J.; Higuchi, W.I.; Fox, J.L.; Spooner, P.J.; Katdare, A.V 289

A New Acid Abrasion Procedure for Studying F Profiles in Demineralized/Remineralized

Bovine Tooth Enamel

Iyer, B.V.; Fox, J.L.; Higuchi, W.I.; Hefferren, J.J.; Vishnupad, K.S

297

Effect of Surface-Active Agents on Fluoride Enamel Interactions. II

Gron, P.; Caslavska, V 304

Accumulation of $\mathrm{Cu}$ and $\mathrm{Zn}$ in Human Dental Plaque in vivo

Afseth, J.; Oppermann, R.V.; Rølla, G 310

Movement of Plaque Fluoride under Cariogenic Conditions

Klimek, J.; Hellwig, E.; Ahrens, G 315

A Mathematical Model of Salivary Clearance of Sugar from the Oral Cavity

Dawes. C 321

VI

Contents

Acid Production from Isomaltulose, Sucrose, Sorbitol, and Xylitol in Suspensions of Human

Dental Plaque (Short Communication) Maki, Y.; Ohta, K.; Takazoe, I.; Matsukubo, Y.; Takaesu, Y.; Topitsoglou, V.; Frostell, G. 335

Animal Studies

A Purified Cariogenic Diet for Rats to Test Sugar Substitutes with Special Emphasis on

General Health

Havenaar, R.; Huis in t’Veld, J.H.J.; Stoppelaar, J.D. de; Backer Dirks, 0340 
Effect of $\alpha$-Amylase and $\alpha$-Glucosidase Inhibitors on Caries Incidence and Plaque Accumu lation in Rats (Short Communication)

Mörmann. J.E.; Schmid, R.; Mühlemann, H.R 353

Clinical Science

Comparison of Diphosphonate Effects on Enamel in vitro and in vivo

Wöltgens, J.H.M.; Koulourides, T 357

A Two-Year Clinical Trial of Sorbitol Chewing Gum

Glass, R.L 365

Effect of Chewing Gums Containing Xylitol, Sorbitol or a Mixture of Xylitol and Sorbitol on

Plaque Formation, pH Changes and Acid Production in Human Dental Plaque

Topitsoglou, V.; Birkhed, D.; Larsson, L.-Å.; Frostell, G 369

Plasma Fluoride Concentrations in Pre-School Children after Ingestion of Fluoride Tablets

and Toothpaste

Ekstrand, J.; Koch, G.; Petersson, L.G 379

No. 5 Basic Sciences

Comparison of Artificial Caries-Like Lesions by Quantitative Microradiography and Microhardness Profiles

Featherstone, J.D.B.; Cate, J.M. ten; Shariati, M.; Arends, J 385

In vivo Investigation on the Fluoride Content in and on Human Enamel after Topical

Applications

Dijkman, A.G.; Boer, P. de; Arends, J 392

Effects of Flow Rate and $\mathrm{pH}$ on Calcium Phosphate Saturation in Human Parotid Saliva

Lagerlöf, F 403

Highly Acid SnF2 and TiF4 Solutions. Effect on Chemical Reaction with Root Dentin in vivo

Tveit, A.B.; Hals, E.; Isrenn, R.; Tøtdal, B

Chemical Stability of Carbonate- and Fluoride-Containing Apatites

LeGros, R.Z.; Tung, M.S 419

Effect of Magnesium and Fluoride on the Fermentative Dissolution of Enamel by a Streptococcal Layer as Measured by Microhardness Tester and a Proton Probe Microanalysis

Luoma, A.-R.; Luoma, H.; Räisänen, J.; Hausen, H 430

In vitro Testing of a New System for Monitoring $\mathrm{pH}$ at Multiple Sites

Yankell, S.L.; Ram, C; Lauks, I.R 439

Binding of Fluoride by Oral Bacteria

Yotis, W.W.; Brennan, P.C 444

Influence of Fluoride Concentration on the Progress of Demineralization in Bovine Enamel

at $\mathrm{pH} 4.5$

(Short Communication)

Arends, J.; Christofferson, J,; Christofferson, M.R.; Schuthof, J 455

Contents VII

Loosely Bound Fluoride Extracted from Natural Carious Lesions after Topical Application of APF in vitro (Short Communication)

Bruun, C; Thylstrup, A.; Uribe, E 458

Scanning Electron Microscopy of Plaque Colonization on Indwelling Glass Electrodes

(Short Communication)

Imfeld, T 461 
Animal Studies

Effects of Varying Intervals between Meals on Dental Caries in Rats

Bowen, W.H.; Amsbaugh, S.M.; Monell-Torrens, S.; Brunelle, J 466

Clinical Science

Clinical Experiments with a Toothpaste Containing Amyloglucosidase and Glucose Oxidase

Afseth, J.; Rølla, G 472

Fluoride Concentration in Whole and Parotid Saliva after Application of Fluoride Var nishes

Seppä, L.; Hanhijärvi, H 476

No. 6 Basic Sciences

SEM and Electron Microprobe Analysis of Enamel Treated with Two-Step Topical Fluorides in vitro

Crall, J.J.; Wefel, J.S.; Clarkson, B.H.; Silverstone, L.M.; Wei, S.H.Y 481

Relation between Acid Dissolution and Histological Alteration of Heated Tooth Enamel

(with 1 color plate)

Sato, K $\quad 490$

Secondary Ion Mass Spectrometry of Human Deciduous Enamel. Distribution of $\mathrm{Na}, \mathrm{K}, \mathrm{Mg}$, $\mathrm{Sr}, \mathrm{F}$ and $\mathrm{Cl}$

Norén, J.G.; Lodding, A.; Odelius, H.; Linde, A 496

Effect of Time and Degree of Saturation of Buffer Solutions on Artificial Carious Lesion

Formation in Human Tooth Enamel

Theuns, H.M.; Dijk, J.W.E. van; Driessens, F.C.M.; Groeneveld, A503

Influence of Fluoride in Solution on Tooth Demineralization. II. Microradiographic Data

Cate, J.M. ten; Duijsters, P.P.E 513

Uptake and Retention of Alkali-Soluble and Alkali-Insoluble Fluoride in Sound Enamel in vivo after Mouthrinses with $0.05 \%$ or $0.2 \% \mathrm{NaF}$

Ögaard, B.; Rölla, G.; Helgeland, K 520

Animal Studies

Influence of Various Diets Administered by Gastric Gavage on Cariogenicity of Foods

Bowen, W.H.; Amsbaugh, S.M.; Monell-Torrens, S.; Brunelle, J.A 525

Clinical Science

Stability of Streptococcus mutans and Its Relationship to Caries in a Child Population over 2 Years

Burt, B.A.; Loesche, W.J.; Eklund, S.A.; Earnest, R.W 532

Calcium and Phosphorus Content of Plaque and Saliva in Relation to Dental Caries

Shaw, L.; Murray, J.J.; Burchell, C.K.; Best, J.S 543

VIII

Contents

Reduced Clinical Effect of Monofluorophosphate in the Presence of Sodium Lauryl Sulfate

Melsen, B.; Rölla, G

Changes in Caries Prevalence of Isle of Lewis Children between 1971 and 1981

Hargreaves, J.A.; Thompson, G.W.; Wagg, BJ

554

Announcements

31th Annual ORCA Congress 1984

ORCA-Rolex Prize 
Honorary Membership

Erratum

561

Acknowledgements

Author Index

562

Subject Index

564

567 